\title{
KONTROWERSJE WOKÓŁ POSTACI EDYTY STEIN
}

Susanne Batzdorff w swoich wspomnieniach zadaje pytanie:

Czy Edyta Stein stanowi przykład pojednania czy przeciwnie, budzi kontrowersje, będąc przeszkodą w dialogu katolicko-żydowskim, utrudniającą wysiłki zbliżenia? Jest to pytanie, z którym zmagają się różne stowarzyszenia Edyty Stein w różnych częściach świata, a problem ten wraca w każdej wiadomości na jej temat ${ }^{1}$.

Jeżeli myśli się poważnie o dialogu chrześcijańsko-żydowskim, w szczególności katolicko-żydowskim, nie sposób nie odnieść się do tej kwestii. Z pewnością katolicy mają prawo do kultu swojej świętej, mają także prawo wyboru formy tego kultu, który - jak to miało miejsce niejednokrotnie przejawia się poprzez budowanie pewnej legendy. Z kolei akademicka debata nad przeszłością i teraźniejszością relacji chrześcijańsko-żydowskich wymaga rzetelnego namysłu, bezstronności i wsłuchiwania się w głosy wielu ludzi: świadków życia Edyty Stein, późniejszych biografów i komentatorów, ludzi głoszących swoje poglądy po jej kanonizacji, teoretyków i praktyków dialogu międzywyznaniowego. Bezstronność jednakże nie może oznaczać szukania prawdy dokładnie "po środku”. Jak wyraził się kiedyś Władysław Bartoszewski, prawda leży tam, gdzie leży. I tak, na przykład, jeżeli rodzina twierdzi, że Edyta Stein słabo znała judaizm i nie była zbyt religijna, czyli porzuciła coś, co nie oddziaływało na nią tak mocno - to nie warto przeciwstawiać temu twierdzeniu świadectw ludzi, którzy nigdy jej

1 S. Batzdorff, Ciocia Edyta. Żydowskie dziedzictwo katolickiej świętej, tłum. M. Grzywacz, Poznań 2011, s. 273. 
nie znali i wypowiadają się o osobie, którą widzą jedynie w aureoli świętości. Podobnie nie warto spekulować, tak jak to czyni Daniel Krochmalnik, jaki rodzaj pobożności reprezentowałaby - obdarzona skłonnością do mistycyzmu - Edyta Stein, gdyby wzrastała w kulturze chasydzkiej, a nie w zasymilowanym środowisku niemiecko-żydowskim².

Dialog jest wartością, aczkolwiek można wyobrazić sobie dwie społeczności żyjące obok siebie w zupełnej izolacji i wzajemnej obojętności, czyli sytuację, w której żadna ze stron nie odczuwa potrzeby zrozumienia sąsiada. O ile było to możliwe przed II wojną światową we wschodnich miasteczkach II Rzeczpospolitej, gdzie życie polskich i żydowskich mieszkańców mogło toczyć się równolegle, czyli osobno, to dzisiaj, gdy myślimy o Polakach i Żydach, byłoby to trudne do wyobrażenia. Pamięć o wojnie, okupacji i Zagładzie łączy bardzo ściśle losy polskie i żydowskie. Jeżeli zatem uważa się w Polsce, nie od dzisiaj zresztą, że dialog jest potrzebny, to jego warunkiem musi być nie tylko otwarcie się na argumenty drugiej strony, ale także coś więcej - aktywna próba zrozumienia jej punktu widzenia, rodzaj empatii czy wczucia, o którym tyle mówi się przy okazji omawiania filozoficznych dokonań Edyty Stein.

Nie musi to być wcale łatwe. Katolikowi, zwłaszcza w Polsce, który modli się do swojej świętej, kanonizowanej przez papieża z Polski, trudno będzie zrozumieć żydowskich krewnych tej osoby, którzy, na przykład, krytykują pewne posunięcia lub wypowiedzi swojej - po prostu - siostry lub cioci. W dialogu uczestniczyć mogą nie tylko głęboko wierzący i praktykujący. Tym mniej religijnym katolikom empatia przyszłaby, być może, łatwiej, gdyby nie to, że - jak sądzę - mało znają problem i o żadnym wczuwaniu się nie myślą. W dialogu bowiem uczestniczą zazwyczaj ci, którzy bardziej się angażują i raczej są gorący aniżeli letni. Bez względu na stopień trudności, umiejętność wyobrażenia siebie $\mathrm{w}$ roli innego oraz umiejętność spojrzenia na pewien problem cudzymi oczyma jest podstawą wyobraźni moralnej, której nie powinno zabraknąć w żadnym dialogu. „Wyobraźnia jest podstawowym narzędziem dobra" - jak twierdził John Dewey³. Warto tutaj podkreślić, że „ja w roli innego" oraz „perspektywa innego" to nie to samo. Łatwiej wyobrazić sobie siebie w sytuacji, w której znalazł się ktoś inny, aniżeli zrozumieć i uznać za pełnoprawny cudzy punkt widzenia. $W$ tym pierw-

2 D. Krochmalnik, Edith Stein. A Jew's path to Catholicism, w: Never forget. Christian and Jewish perspectives on Edith Stein, red. W. Herbstrith OCD, transl. S. Batzforff, Wellesley (MA) 2012, s. 67.

${ }^{3}$ J. Dewey, Art as experience, cyt. za: P.H. Werhane, Moral imagination and management decision making, New York - Oxford 1999, s. 91. 
szym przypadku to wciąż jestem ",ja", natomiast w drugim - mam do czynienia z rzeczywistą „innością"4.

Spróbujmy zatem zrozumieć żydowski punkt widzenia. Ułatwiają to wypowiedzi sporej liczby osób, a wśród nich cytowanej już tutaj Susanne Batzdorff (siostrzenicy Edyty Stein), Abrahama Foxmana i rabina Klenickiego (dyrektorów Anti-Defamation League) czy Stanisława Krajewskiego (profesora UW, który wygłosił odczyt w Centrum Dialogu i Modlitwy w Oświęcimiu w 2006 roku).

W liberalnym społeczeństwie zmiana przynależności religijnej jest sprawą prywatną. Także wśród Żydów jest wiele osób mało religijnych, dla których problem indywidualnej konwersji nie jest źródłem większych emocji. Możemy jednak tak myśleć dzisiaj, w sytuacji zasadniczo różnej od atmosfery lat dwudziestych ubiegłego wieku, nie mówiąc już o latach trzydziestych, gdy zamiary nazistów stały się aż nadto czytelne. Decyzja Edyty Stein (zwłaszcza ta dotycząca wstąpienia do klasztoru) podjęta została w określonym kontekście historycznym, w którym musiała budzić niepokój rodziny i przyjaciół, bez względu na stopień ich religijności. Już wówczas nie było to wydarzenie czysto prywatne, nie mówiąc o jego wymiarze w perspektywie tego, co wydarzyło się 64 i 76 lat później, to znaczy wobec faktu beatyfikacji i kanonizacji św. Teresy Benedykty od Krzyża.

Rodzina Edyty Stein wybór swojej krewnej odczuła bardzo boleśnie. W społeczeństwie, które przez wyznawców danej religii uważane jest za mało tolerancyjne, konwersja budzi lęk, poczucie zagrożenia i rzeczywiście przestaje być sprawą prywatną. Wciąż żywa była pamięć przymusowych konwersji, a także istniała świadomość, że te dobrowolne często były dyktowane chęcią uniknięcia sankcji społecznych - w postaci zamkniętej drogi do kariery zawodowej, w tym akademickiej - za bycie Żydem czy Żydówką.

Konwersja Edyty Stein odbierana była przez jej rodzinę jako utrata bliskiej osoby. Jej wstąpienie do zakonu w 1933 roku, w trudnym dla niemieckich Żydów momencie, gdy nawet ci mało religijni szukali jedności z własnym środowiskiem, odbierane było jako jeszcze boleśniejsza strata, a nawet zdrada tego środowiska, jeśli wziąć pod uwagę poczucie zagrożenia, które wywoływały poczynania Hitlera jako kanclerza Rzeszy Niemieckiej5.

\footnotetext{
${ }^{4}$ Filozoficzną debatę nad problemem wyobraźni moralnej podsumowuje P.H. Werhane, Moral imagination..., dz. cyt., s. 91-107.

${ }^{5}$ S. Batzdorff, dz. cyt., s. 113.
} 
Pojęcie utraty jest tu jednak kluczowe. Edyta Stein nie opuściła rodziny tak po prostu, wyjeżdżając, zaprzestając z nią kontaktów i stając się kimś innym, jak to się często dzieje $\mathrm{z}$ dziećmi, które wyjeżdżają na studia i po wielu latach czują, że nie łączy ich zbyt wiele z rodzinnymi stronami. Stała się siostrą zakonną, odciętą od świata, a po śmierci świętą. Oznaczało to proces utraty symbolicznej, której źródłem było również przeinterpretowanie przez samą siostrę Teresę (oraz, siłą rzeczy, późniejszych jej czytelników) jej prywatnego życia, życia jej rodziny, a nawet jej percepcji ówczesnych wydarzeń historycznych. Cytuje się często wypowiedź samej Edyty Stein: "Co nie było zgodne z moim planem, było częścią planu Bożego"6.

Przyszła Karmelitanka pamięta, że przestała się modlić w wieku 15 lat. Jej siostrzenica pyta jednak, czy było to oznaką planu Bożego, czy też wynikiem burzy emocjonalnej dojrzewającej nastolatki ${ }^{7}$. Ta sprowadzająca wszystko na ziemię psychologiczna diagnoza wcale nie musi oznaczać chęci kompromitowania katolickiej świętej, lecz jedynie to, iż rodzina nie chce wyrzekać się własnej pamięci o krewnej. Nawet jeżeli ona sama, po latach, widzi własne życie inaczej. Krewni Edyty Stein nie chcą tracić historii rodzinnej z powodu takiej reinterpretacji przeszłości dokonanej przez samą świętą, ani tym bardziej za sprawą hagiograficznych narracji ${ }^{8}$. Dom rodzinny Edyty Stein nie był zbyt religijny, jak twierdzą ${ }^{9}-w$ wielu opracowaniach przeczytać mogą jednak coś odwrotnego. Zdaniem Susanne Batzdorff, cel takich opowieści jest jeden: „opisuje się przytłaczającą atmosferę ortodoksji, aby uzasadnić wyobcowanie wrażliwej natury Edyty w jej wierze i zwrócenie się ku chrześcijaństwu"10. Tymczasem Edyta Stein, zdaniem rodziny, słabo znała tradycje żydowskie, nie rozumiała znaczenia wielu praktyk religijnych i obyczajowych. Podobnie zresztą jak jej siostra, Erna. Relacja Susanne Batzdorff jest bardzo przekonująca i dotyczy faktów z życia rodziny, które łatwo sprawdzić, podobnie jak można je porównać z ich interpretacją dokonaną przez samą Edytę Stein ${ }^{11}$.

Batzdorff podkreśla „zwykłość” młodości Edyty Stein, co nie ma oczywiście na celu negowania jej niezwykłych cech charakteru, wrażliwości, uzdolnień oraz ambicji, lecz ma pomóc $\mathrm{w}$ zachowaniu pamięci o bliskiej osobie, której nie chce się stracić po raz drugi. To życie krewnej, o którym chce się pamiętać w rodzinie, obejmuje także fascynację Edyty Hansem Bi-

\footnotetext{
6 Tamże, s. 94.

7 Tamże, s. 93.

8 Tamże, s. 126, 197.

9 Tamże, s. 264-265.

10 Tamże, s. 127.

11 Tamże, s. 250-252.
} 
bersteinem, która nie słabnie nawet w dniu jego ślubu z Erną, czyli jej własną siostrą, związki z Hansem Lippsem czy wreszcie znajomość z Romanem Ingardenem ${ }^{12}$.

Nawet jeżeli pewne zdarzenia były bolesne dla samej Edyty Stein, stanowiły przecież część jej życia, które także rodzina przeżywała i które dobrze zapamiętała jako własną historię. Oczywiście, wszystkie swoje niepowodzenia Edyta Stein ma prawo tłumaczyć planem Bożym. Niemniej jako dzisiejsi jej interpretatorzy nie możemy zapominać, iż mamy do czynienia $\mathrm{z}$ autobiografią. Jej autorka ma prawo do autokreacji - tak jak każdy autor. Nikt nie zna planów Bożych, które niejako z definicji są niepoznawalne w fazie, gdy są jeszcze planami. Można je jedynie odczytać po fakcie, a i tak czynność ta jest zawsze mniej lub bardziej subiektywną interpretacją. A zatem osoba pisząca ma prawo do kreowania własnej biografii, a czytelnicy, zwłaszcza ci, którzy ją znali osobiście, mają prawo widzieć poszczególne wydarzenia i fakty inaczej.

Żydzi mogą czuć się dotknięci do żywego mówieniem o planach Bożych w sytuacji, gdy były to plany iście diabelskie. I tak, nie rezultatem planów niebios, lecz przyziemnym i powszechnym wynikiem prześladowań Żydów w tamtych czasach było to, że wśród wykładowców Edyty Stein „wielu jej nauczycieli pochodzenia żydowskiego zostało chrześcijanami. Był to często pragmatyczny krok przewidziany $\mathrm{w}$ celu umożliwienia kariery na uczelni"13. Dzisiaj używa się terminu „szklany sufit”, aby opisać niewidoczną barierę uniemożliwiająca awans zawodowy kobiet w wielu organizacjach. Wówczas był to dobrze widoczny, oczywisty dla każdego betonowy sufit: kobieta i Żydówka nie mogła zrobić akademickiej kariery. A zatem kiedy Susanne Batzdorff pyta, czy to było częścią Bożego planu, trudno nie rozumieć przyczyn tego sarkazmu. Jednocześnie sama przyznaje, że w czasach jej młodości ,judaizm miał niewiele do zaoferowania" kobiecie ${ }^{14}$. I to też nie było częścią Bożego planu, lecz wynikiem interpretacji Pisma w tak zwanym społeczeństwie tradycyjnym.

W dyskusjach na temat życia Edyty Stein zdarza się słyszeć argument padający ze strony katolików, a sprowadzający się do pytania, kim jest siostrzenica świętej, że dajemy wiarę wszystkiemu, co napisze i powie o swojej ciotce. Sądzę jednak, iż podważanie świadectwa Susanne Batzdorff nie ma sensu, a ponadto nie służy dobrze dialogowi katolicko-żydowskiemu. Jeżeli chcemy poznać żydowski punkt widzenia, to właśnie Ciocia Edyta byłaby

12 Tamże, s. 137-138, 244-246.

13 Tamże, s. 157.

14 Tamże, s. 253. 
tym pierwszym, aczkolwiek nie jedynym, źródłem wiedzy - źródłem, w sumie, niezależnym, mającym dystans względem niepokojów duchowych i objawień religijnych tytułowej postaci. Zaryzykowałbym twierdzenie, iż jako przykład żydowskiego punktu widzenia wspomnienia Susanne Batzdorff są bardziej wiarygodne od pism autobiograficznych samej św. Teresy, która właśnie pragnie uwolnić się od swojej dawnej przynależności i perspektywy, o czym świadczy wiele fragmentów jej prac.

Na przykład wspominając Maxa Schelera, jego osobowość i jego katolicyzm, nie kryje swojej fascynacji tą formą religijności.

Było to moje pierwsze zetknięcie się z nieznanym mi dotąd światem. Nie doprowadziło mnie jeszcze do wiary, ale otwarło pewien zakresu "fenomenu”, obok którego nie mogłam przejść jak ślepiec. Nie na darmo wpajano nam stale zasadę, abyśmy do każdej rzeczy podchodzili bez uprzedzeń, odrzucając wszelkie "obawy”. Jedne po drugich, opadały ze mnie więzy racjonalistycznych przesądów, w jakich wzrastałam, nie wiedząc o tym, i nagle stanął przede mną świat wiary ${ }^{15}$.

W każdym razie problem „Bożego planu” prowadzi nas do kluczowej różnicy perspektyw pojawiającej się w odniesieniu do tego, jak postrzegana jest śmierć Edyty Stein, a zatem w kwestii niezwykle ważnej dla stosunków katolicko-żydowskich. Czy śmierć Edyty Stein w komorze gazowej była częścią tego planu? Czy Holokaust w takim razie był również częścią tego planu?

A.H. Foxman i rabin L. Kliencki pisali w 1998 roku, co oznacza dla Żydów kanonizacja św. Teresy Benedykty od Krzyża.

Byłoby rzeczą zrozumiałą oddawanie czci chrześcijańskiemu męczeństwu, gdyby nie to, że dokonuje się za cenę ignorowania faktu, iż Holocaust był co do swojej istoty programem eksterminacji narodu żydowskiego. [...] Jako Żydzi czujemy, że straciliśmy Edytę Stein dwukrotnie. Po raz pierwszy za sprawą jej konwersji na katolicyzm. Po raz drugi w chwili jej kanonizacji, na mocy której pewne ugrupowania przywłaszczają ją sobie jako chrześcijańską męczennicę, pomimo faktu, iż jej śmierć ma związek z Zagładą Żydów. Edyta Stein postrzegana w ten sposób staje się żydowskim pretekstem dla chrześcijańskich usprawiedliwień, jakoby Kościół był także ofiarą, a zatem ofiarą własnych antyżydowskich praktyk skierowanych przeciwko niewinnym Żydom. Dlaczego Edyta Stein, a nie Franz Jägerstätter, skromny austriacki katolik ścięty przez nazistów w 1943 roku za odmowę walki w hitlerowskich oddziałach? Dlaczego nie polski katolicki wieśniak, który ukrywał Żydów, lub opiekunka, która przyjęła żydowskie dziecko jako swoje własne?16

${ }^{15}$ E. Stein, Dzieje pewnej żydowskiej rodziny, tłum. J.I. Adamska OCD, Kraków 2000, s. 207-208.

16 A.H. Foxman, Rabbi L. Klenicki, The canonization of Edith Stein. An unnecessary problem, October 1998, http://archive.adl.org/opinion/edith_stein.html [dostęp: 1.02.2014]; jest to 
Zarzut zawłaszczania Zagłady (owa druga utrata Edyty Stein) pojawia się wielokrotnie od czasu jej beatyfikacji. Jeżeli jednak chcemy rozumieć żydowski punkt widzenia, ten moment byłby kluczowy. Uzmysławia nam to przemówienie Stanisława Krajewskiego wygłoszone w Oświęcimiu w 2006 roku.

Choć wierzę - mówił on - że Kościół nie miał intencji zawłaszczania Holokaustu a należy dodać, że wielu Żydów jest podejrzliwych w tym względzie - to jednak pozostaje faktem, że Edyta Stein uczyniona została wyróżnionym reprezentantem ofiar. Nie da się uciec od pytania, co dla pamięci o Zagładzie oznacza fakt uczynienia katolickiej świętej przedstawicielką ofiar, jedną z bardzo nielicznych twarzy reprezentującą masy bezimiennych ofiar obozów śmierci. Nie powinna dziwić powracająca wątpliwość, czy nie prowadzi to do zawłaszczania, chrystianizacji Zagłady ${ }^{17}$.

Edyta Stein została zamordowana jako Żydówka wraz z milionami innych Żydów, kobiet i mężczyzn, starców i dzieci. Nie poszła na śmierć za swoją nową wiarę, lecz za przynależność do narodu żydowskiego. Trudno dziwić się jej siostrze Ernie, która „miała trudności z zaakceptowaniem koncepcji męczeństwa Edyty, ponieważ, poza nią, straciła dwie inne siostry i brata $w$ nazistowskiej maszynie zniszczenia, nie wspominając już o milionach innych, którzy również stracili życie w holokauście"18.

Edyta Stein umarła tak, jak pozostali Żydzi zagazowani przez nazistów. Wszyscy oni zginęli śmiercią męczeńską. Trudno też oprzeć się pytaniu, dlaczego właśnie Edyta Stein została wyróżniona przez Kościół wyniesieniem na ołtarze. Równie trudno powstrzymać się od kolejnego pytania, czy tym zasadniczym powodem nie była jej wcześniejsza konwersja, której konsekwencją po jakimś czasie było wstąpienie do klasztoru? Towarzyszący historii Kościoła problem nawracania Żydów to trudny temat w rozmowach Żydów i katolików. To także - śmiem twierdzić - przeszkoda w zrozumieniu żydowskiego punktu widzenia w kwestii wymowy życia i świętości Edyty Stein. Bardzo często katolicy nie rozumieją, dlaczego podnosi się kwestię konwersji w kontekście kanonizacji Edyty Stein. Przecież chrześcijaństwo jest „logicznym” dopełnieniem judaizmu, a życiowa droga św. Teresy pozostaje zgodna $\mathrm{z}$ tą logiką ${ }^{19}$. Argument ten tylko umacnia obawy

archiwalna strona Ligi Przeciw Zniesławieniu (Anti-Defamation League). Warto pamiętać, że sam Foxman został ocalony przez swoją mamkę, która ochrzciła go w jednym $\mathrm{z}$ wileńskich kościołów.

17 S. Krajewski, Sprawa Edyty Stein, Centrum Dialogu i Modlitwy w Oświęcimiu, 2006, www.cdim.pl [dostęp: 1.09.2013).

18 S. Batzdorff, dz. cyt., s. 192-193.

${ }_{19}$ Także o tych poglądach wielu katolików mówił Stanisław Krajewski w Oświęcimiu. Argumenty te pojawiły się również podczas dyskusji w trakcie konferencji „Fenomen Edyty Stein" w Poznaniu (UAM 2013). 
Żydów, iż kanonizacja Edyty Stein mogła być swego rodzaju nagrodą za konwersję, i w efekcie nie służy dobrze prawdziwemu dialogowi.

W 2006 roku Stanisław Krajewski przyznał, iż mogłoby się wydawać, że wszystko już zostało powiedziane na temat różnic w postrzeganiu kanonizacji Edyty Stein, niemniej jednak akurat w Polsce sprawa ta nie została poważnie przedyskutowana i dlatego warto do tego tematu wracać. Osiem lat później można powtórzyć te słowa. Tyle już powiedziano i napisano, ale podczas kolejnych konferencji i dyskusji okazuje się, że postać Edyty Stein wciąż raczej dzieli niż zbliża środowiska żydowskie i katolickie. Naprawdę, poważna dyskusja jeszcze przed nami.

\section{The Controversies over the Figure of Edith Stein}

\section{Summary}

Is Edith Stein a symbol of reconciliation between Jews and Catholics or just the opposite - a major stumbling block? This question was asked by Susanne Batzdorff, Edith Stein's niece, in her memories. It should be repeated today if we try to approach seriously the theme of Catholic-Jewish dialogue. For many Catholics, it is not easy to understand the Jewish point of view regarding the canonization of St. Teresa Benedicta of the Cross. Therefore the aim of this article was to present this perspective and its justification, the understanding of which seems to be a precondition of a real dialogue, the dialogue where both sides are given the same right to express their thoughts, claims and reservations.

The relatives of Edith Stein and Jewish commentators on her life and death underline that they have lost Edith Stein twice: first, when she made her conversion to Catholicism and, second, after her death, when she became a symbol of Christian martyrdom, the fact which finally led to her canonisation in 1998. In their eyes, Edith Stein had faced discrimination during her professional career and died in the gas chamber as a Jew. She was refused tenure at German universities as a Jew and as a woman. Obviously, as a Catholic nun, Edith Stein herself had the right to read these facts as an evidence of a pre-existing God's plan: all her personal failures were meant to lead to a final and essential victory made possible by her conversion. But the Jewish perspective, for obvious reasons, is different: the Jewish community lost one of its members in a period when integration seemed natural in the face of the Nazi threat. The second loss of Edith Stein was a symbolic one: canonisation made her one of Catholic saints - despite the fact that she died as a Jew along with millions of other victims of the Shoah. Was her death a part of God's project to convoke her to sanctity? Should we understand that the Holocaust was also part of the same plan? 
The second loss, in fact, is connected with the symbolic appropriation of the Holocaust by the Catholic Church by underlying the Christian martyrdom evidenced by the death of Edith Stein. In view of the fact that she died together with six millions other Jews, the question arises why her martyrdom led only her to sanctity and not any other Jews? Was her conversion a reason why she was such rewarded? For Jews, it is both tragic and paradoxical that Edith Stein converted to Catholicism which for centuries has blamed Jews for killing Jesus Christ and has instigated anti-Semitism. The latter finally led to Hitler's plan of the final solution. Even today, among Catholics, a claim can be heard that conversion to Christianity is a logical step, natural consequence, and kind of compensation once a Jew admits that it was a historical mistake not to recognise Jesus Christ as the Son of God. Therefore it would be natural to honour Edith Stein for her decision to convert. In conclusion, the author of the article states once more that without understanding the Jewish perspective on life and death of Edith Stein neither a dialogue nor reconciliation is possible between Jews and Catholics. 